ВІСНИК

ОДЕСЬКОГО НАЦІОНАЛЬНОГО

МОРСЬКОГО УНІВЕРСИТЕТУ

№ 3 (60), 2019
HERALD

OF THE ODESSA NATIONAL

MARITIME UNIVERSITY № $3(60), 2019$

УДК 629.5.01

DOI 10.33082/2226-1893-2019-3-25-48

\title{
УЧЕТ МОДЕРНИЗАЦИЙ И ВЫБЫТИЯ ФЛОТА ОТЕЧЕСТВЕННЫХ РЕЧНЫХ КРУИЗНЫХ ПАССАЖИРСКИХ СУДОВ ПРИ ОЦЕНКЕ ПЕРСПЕКТИВ РЕЧНОГО КРУИЗНОГО РЫНКА
}

\author{
А.Г. Егоров \\ к.т.н., ст. научн. сотрудник \\ Морское инженерное бюро, г. Одеса, Украина
}

Аннотация. При разработке проектов новых речных круизных пассажирских судов (РКПС) и модернизаџии существуюших крайне важно иметь представление о реальной ситуации с фактической пассажировместимостью РКПС. Для решения поставленной задачи были исследованы 113 имеюших действуюший класс на 2019 год РКПС. Существенно модернизировано с повышением уровня комфортабельности 43 круизных пассажирских судна $(38,7$ \% от всех работающих в навигаиию 2019 года).

При существенной модернизачии РКПС из первой группь (суда проектов 26-37, 588, 305, 646) пассажировместимость в среднем уменьшается на 52,3\%, при сохранении философии - на $32 \%$. При существенной модернизации РКПС из второй группы (проекты 301, 302, Q-040, Q-056, Q-065, 92-016) - на $37 \%$, при сохранении философии - на 16,1\%.

К 2030 году прогнозируется уменьшение пассажсировместимости на 52,72\% до 11631 человека, и это, не считая возможного уменьшения пассажировместимости за счет глубокой модернизации существующих круизных судов для повышения уровня комфортабельности в 2019-2030 годы. При этом также не учитываются возможные новые РКПС, которые будут заказаны и построены (либо переоборудованы из других типов судов), начиная с 2020 года.

Для сохранения понятия "речной круиз», и не только для иностранных туристов, рекомендуется на среднесрочную и долгосрочную перспективы строительство новых пассажирских судов, которые бы наиболее полно удовлетворяли запросам рынка. Это могут быть круизные пассажирские суда как для классических речных маршрутов в европейской части страны (PV300, PV500VB, PV09, ПКС-180 и т.n.), так и смешанного плавания суда для работы в прибрежных морях и на речных маршрутах в восточной части (PV300VD, PV11, PV11M и m.n.).

Ключевые слова: речные круизы, пассажировместимость, утилизация, модернизация, конверсия, комфортабельность, прогноз.

(C) Егоров А.Г., 2019 
ВІСНИК

ОДЕСЬКОГО НАЦІОНАЛЬНОГО

МОРСЬКОГО УНІВЕРСИТЕТУ
HERALD

OF THE ODESSA NATIONAL

MARITIME UNIVERSITY № $3(60), 2019$

УДК 629.5.01

DOI 10.33082/2226-1893-2019-3-25-48

\title{
ВРАХУВАННЯ МОДЕРНІЗАЦЙ ТА ВИБУТТЯ ФЛОТУ ВІТЧИЗНЯНИХ РІЧКОВИХ КРУЇЗНИХ ПАСАЖИРСЬКИХ СУДЕН ПІД ЧАС ОЦІНЮВАННЯ ПЕРСПЕКТИВ РІЧКОВОГО КРУЇЗНОГО РИНКУ
}

\author{
О.Г. Сгоров \\ к.т.н., ст. наук. співпрацівник
}

Морське інженерне бюро, м. Одеса, Україна

Анотація. При розробиі проектів нових річкових круїзних пасажирських суден (РКПС) і модернізаџї існуючих вкрай важливо мати уявлення про реальну ситуацію з фактичною пасажиромісткістю РКПС. Для вирішення поставленого завдання було досліджено 113 суден, які мають діючий клас на 2019 рік. Істотно модернізовано з підвищенням рівня комфортабельності 43 круїзних пасажирських судна $(38,7$ \% від усіх праиюючих в навігаџію 2019 року).

При істотній модернізаиії РКПС з першої групи (судна проектів 26-37, 588, 305, 646) пасажиромісткість в середньому зменшується на 52,3\%, при збереженні філософії - на $32 \%$. При істотній модернізаиї̈ РКПС з другої групи (проекти 301, 302, Q-040, Q-056, Q-065, 92-016) - на $37 \%$, при збереженні філософії-на 16,1\%.

До 2030 року прогнозується зменшення пасажиромісткості на $52,72 \%$ до 11631 людини, $і$ ие, не враховуючи можливого зменшення пасажиромісткості за рахунок глибокої модернізачії існуючих круїзних суден для підвищення рівня комфортабельності в 2019-2030 роки. При цьому також не враховуються можливі нові РКПС, які будуть замовлені $i$ побудовані (або переобладнані з інших типів суден), починаючи 3 2020 року.

Для збереження поняття «річковий круїз», і не тільки для іноземних туристів, рекомендується на середньострокову $i$ довгострокову перспективи будівництво нових пасажирських суден, які б найбільш повно задовольняли запитам ринку. Це можуть бути круїзні пасажирські судна як для класичних річкових маршрутів в європейській частині краӥни (PV300, PV500VB, PV09, ПКС-180 і т.n.), так і змішаного плавання судна для роботи в прибережних морях $i$ на річкових маршрутах в східній частині (PV300VD, PV11, PV11M і m.n.).

Ключові слова: річкові круїзи, пасажиромісткість, утилізачія, модернізація, конверсія, комфортабельність, прогноз. 
ВІСНИК

ОДЕСЬКОГО НАЦІОНАЛЬНОГО

МОРСЬКОГО УНІВЕРСИТЕТУ

№ 3 (60), 2019
HERALD

OF THE ODESSA NATIONAL

MARITIME UNIVERSITY

№ 3 (60), 2019

UDC 629.5.01

DOI 10.33082/2226-1893-2019-3-25-48

CONSIDERATION OF MODERNIZATIONS AND NATIVE RIVER CRUISE PASSENGER SHIPS FLEET DECOMMISSIONING WHILE EVALUATION OF PERSPECTIVES OF RIVER CRUISE MARKET

\author{
A.G. Egorov \\ Candidate of Technical Sciences, Senior Researcher \\ Marime Engineering Bureau, Odessa, Ukraine
}

\begin{abstract}
When developing projects of new river cruise passenger ships (RCPS) and modernizing existing ones it is extremely important to have information of real situation with actual passenger capacity of RCPS. To solve this problem 113 RCPS with valid class for 2019 were researched. 43 cruise passenger ships $(38,7 \%$ of all working in navigation in 2019) were significantly upgraded with level of comfort increase. Modernization and reequipment works are ongoing. In the last five years 34 vessels have been modernized (32 in Russia plus two Dnipro ships of 301 project).

An average estimation of influence of modernization on passenger capacity of river cruise passenger ships was also executed. On significantly modernized RCPS from the first group (ships of 26-37, 588, 305, 646 projects) passenger capacity decreases at the mean by $52,3 \%$, on insignificantly modernized ships - by $32 \%$. On significantly modernized RCPS from the second group (301, 302, Q-040, Q-056, Q-065, 92-016 projects) passenger capacity decreases at the mean by $37 \%$, on insignificantly modernized ships by $16,1 \%$.

Total passenger capacity of river cruise passenger ships operating in 2019 was calculated, mean age of working ships was determined, passenger capacity forecast for mid-term perspective up to 2030 was given. By 2030 passenger capacity will be decreased by 52,72\% to 11631 people without taking in account possible decrease due to deep modernization of existing cruise ships and ships which can be ordered and built (or conversed from other ship types) in 2019-2030.

To keep "river cruise» concept, and not only for foreign tourists, it is recommended for mid and long term to build new passenger ships that would most fully satisfy demands of the market. These can be cruise passenger ships both for classic river routes in European part of the country (PV300, PV500VB, PV09, PKS-180, etc.), as well as river-sea ships for work at coastal seas and on Eastern river routes (PV300VD, PV11, PV11M etc.).
\end{abstract}

Keywords: river cruises, passenger capacity, utilization, modernization, conversion, comfortableness, prognosis.

Постановка проблемы. Рынок речных круизных перевозок, несмотря на кризисные явления начала XXI века, продолжает развиваться: строятся новые речные круизные пассажирские суда (РКПС), в 
том числе с использованием судов-доноров [1-3], переоборудуются и модернизируются старые [4], появляются новые взгляды на организацию круизов, новые маршруты [5-8].

Такое развитие - вполне адекватная реакция рынка на спрос со стороны клиентов (растет платежеспособность, повышаются требования к качеству круиза, увеличивается спрос у иностранных туристов на круизы не только на классических линиях Киев-Херсон - Одесса. Москва Санкт-Петербург, но и, к примеру, на частично морские линии с выходом в Черное и Каспийское моря, на круизы по восточным рекам).

Но далеко не все существующие РКПС переоборудованы и модернизированы под современные понятия круизного судна, да и, как показало исследование [9], не все проекты одинаково подходят для переоборудования, затраты могут достигать $30-50 \%$ от стоимости нового судна, как следствие - утилизация определенной части РКПС.

Общая пассажировместимость отечественных РКПС, при этом, продолжает снижаться как за счет списания судов, так и за счет уменьшения числа мест при повышении комфортабельности во время переоборудований.

При разработке проектов новых РКПС и модернизации существующих крайне важно иметь представление о реальной ситуации с фактической пассажировместимостью РКПС, поэтому настоящее исследование представляется актуальным и своевременным.

Целью статьи является определение фактической пассажировместимости работающих РКПС с прогнозом до 2030 года.

Изложение основного материала. Для решения поставленной задачи были исследованы 113 имеющих действующий класс РРP (на 2019 год) РКПС - см. таблицу 1.

В таблице 1 приведены также два круизных судна проекта 301 «Викинг Синеус» и «Принцесса Днепра», работающие на Днепре, круизное судно проекта 1168 «Белая Русь», выполняющее круизы в Беларуси, а также два судна проекта ПКС-40 и судно проекта 1877 «Россия», которые не совершают круизы.

Было выявлено, что все суда в той или иной степени были переоборудованы или модернизированы (см. таблицу 2).

При этом под понятием «сохранение философии» автор понимал такой тип модернизации, при которой сохранялся уровень комфортабельности.

В свою очередь, «существенная модернизация», соответственно, была направлена на повышение уровня комфортабельности судна.

Существенно модернизировано с повышением уровня комфортабельности 43 круизных пассажирских судна $(38,7 \%$ от всех работающих в навигацию 2019 года). 
욜

\begin{tabular}{|c|c|c|c|c|c|c|c|c|c|c|c|}
\hline 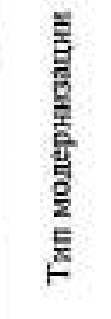 & 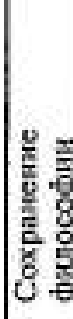 & & 送 & 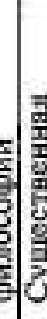 & 产 & 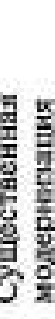 & 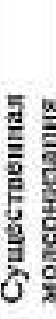 & & & & \\
\hline 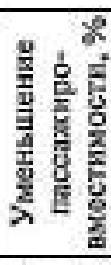 & Ẽ & $\frac{f}{d}$ & & & ta & लె & $\begin{array}{l}\text { î. } \\
\text { ô }\end{array}$ & 点 & $\stackrel{5}{4}$ & 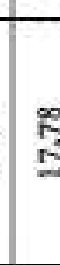 & \\
\hline 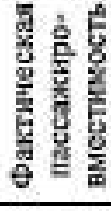 & 劣 & $E$ & 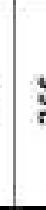 & & d & ন & $\frac{\pi}{4}$ & శె & 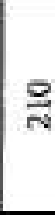 & ఝ & \\
\hline 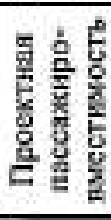 & $\underset{m}{8}$ & 8 & 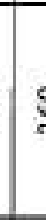 & & 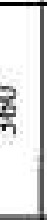 & 吕 & $8_{\infty}$ & $p_{\infty}$ & $\underset{\sim}{8}$ & ళ్ల & \\
\hline 둥 & : & $\stackrel{\text { J }}{2}$ & 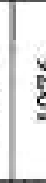 & & 参 & 욤 & S5 & $\overrightarrow{\mathrm{o}}$ & 急 & 蕃 & \\
\hline 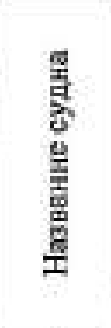 & 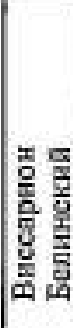 & 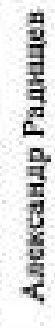 & 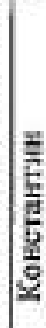 & : & 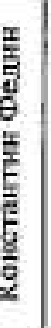 & 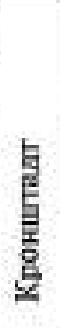 & 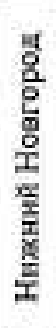 & 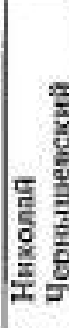 & 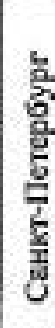 & 量 & \\
\hline $\begin{array}{l}\text { to } \\
\text { 总 } \\
\text { E. }\end{array}$ & $\bar{g}$ & $\bar{్}$ & $\bar{T}$ & & $\vec{b}$ & $\overrightarrow{\mathrm{p}}$ & ర్ల & $\bar{p}$ & 点 & $\bar{D}$ & \\
\hline 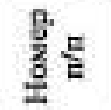 & - & $N$ & r & & 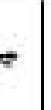 & $n$ & ${ }^{\circ}$ & 12 & $\infty$ & 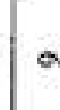 & \\
\hline
\end{tabular}




\begin{tabular}{|c|c|c|c|c|c|c|c|c|c|c|c|}
\hline 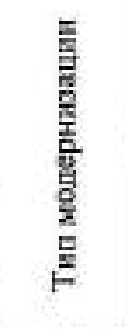 & 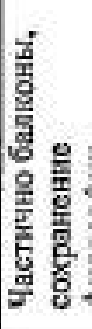 & 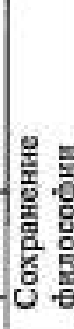 & & 5 & 18 & 偪 & 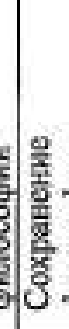 & 证 & & & 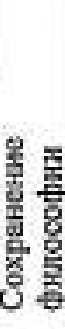 \\
\hline 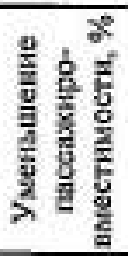 & $\underset{f}{\mathbb{f}}$ & $\underset{ \pm}{ \pm}$ & 疍 & $\begin{array}{l}{ }_{0}^{\circ} \\
\text { f }\end{array}$ & ڤొ & $\stackrel{\text { g }}{=}$ & $\begin{array}{l}\text { নี } \\
\text { নี }\end{array}$ & $\begin{array}{l}\text { స్ } \\
\frac{5}{q}\end{array}$ & & & 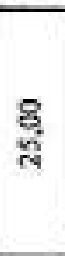 \\
\hline 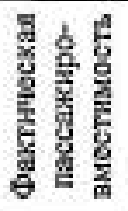 & స్ల & 总 & নై & ह्रे & $\approx$ & ल & ఖ్లి & $\stackrel{\sim}{\sim}$ & ‡ & & 8 \\
\hline 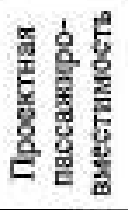 & : & : & : & 总 & : & झ & \& & ళ & 8 & 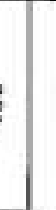 & 号 \\
\hline 韋 & 气ิ & 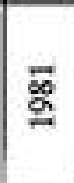 & $\stackrel{\circ}{\circ}$ & E & S & $\stackrel{\varrho}{\varrho}$ & 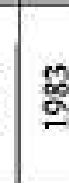 & 气̆ & 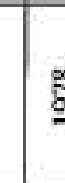 & & gे \\
\hline 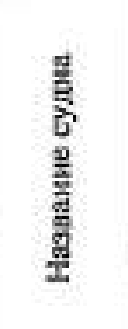 & 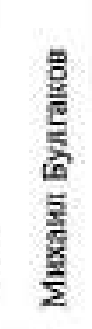 & 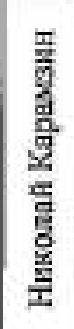 & $\begin{array}{l}\text { 胥 } \\
\text { ¿ }\end{array}$ & 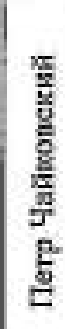 & 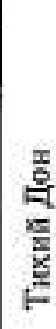 & 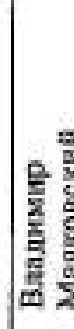 & 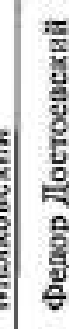 & 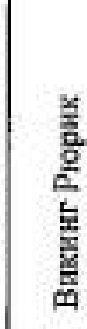 & 声 & 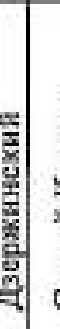 & 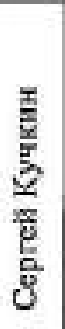 \\
\hline $\begin{array}{l}\text { to } \\
\text { o. } \\
\text { ․․ㄹ }\end{array}$ & 官 & 하 & $\bar{p}$ & $\vec{p}$ & $\overline{\mathrm{m}}$ & $\overline{\bar{\rho}}$ & ్ㅗㅁ & 鬲 & 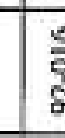 & & 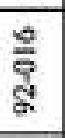 \\
\hline 홍몸 & $=$ & $\simeq$ & $\underline{2}$ & \pm & $\simeq$ & $\simeq$ & $\Xi$ & $\stackrel{\infty}{\Perp}$ & 9 & & శ్ \\
\hline
\end{tabular}




\begin{tabular}{|c|c|c|c|c|c|c|c|c|c|c|}
\hline 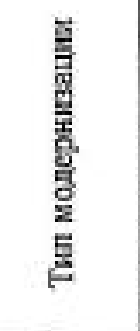 & 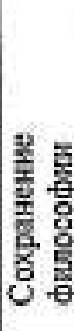 & 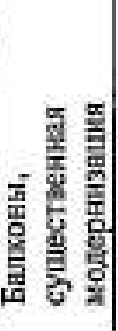 & 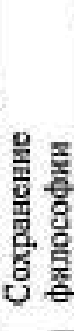 & 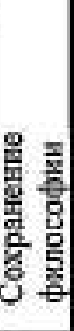 & 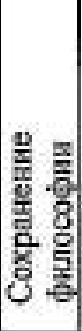 & 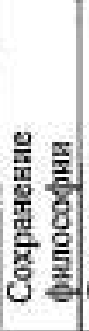 & 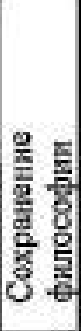 & 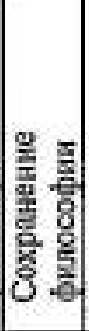 & 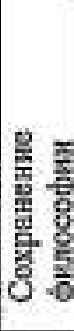 & 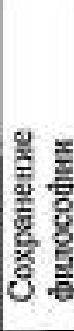 \\
\hline 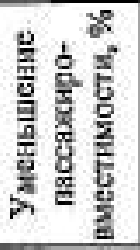 & $\begin{array}{l}8 \\
\infty \\
-\infty\end{array}$ & $\begin{array}{l}8 \\
7 \\
7\end{array}$ & तે & ปे & ถิํํ & ๗2 & ฮู & $\stackrel{\text { त् }}{\stackrel{0}{\varrho}}$ & 갱 & $\stackrel{8}{\sharp}$ \\
\hline 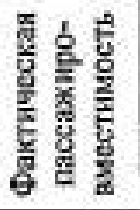 & $\underset{m}{\stackrel{m}{m}}$ & $\frac{d}{\pi}$ & s్ & gे & $\frac{\infty}{m}$ & 嵒 & సี & శ్ & 莽 & ఫ్తు \\
\hline 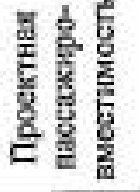 & 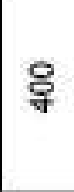 & ళ్ & 亲 & $\S$ & 8 & ન్ & হ్ & ભ్ & 갥 & 鬲 \\
\hline 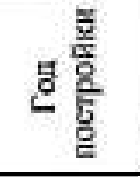 & $\stackrel{2}{\beth}$ & 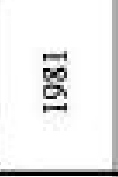 & 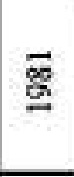 & $\vec{g}$ & $\underset{2}{2}$ & 棁 & \$ & $\stackrel{2}{\%}$ & $\stackrel{\circ}{\stackrel{\circ}{2}}$ & $\stackrel{2}{\stackrel{0}{2}}$ \\
\hline 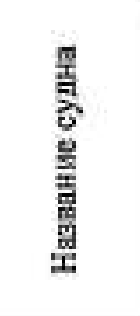 & 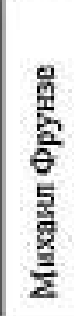 & 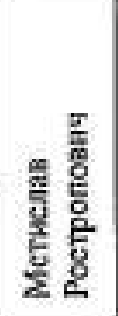 & 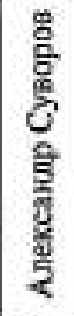 & 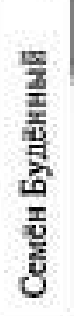 & 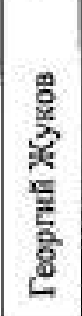 & 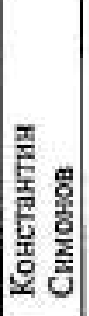 & 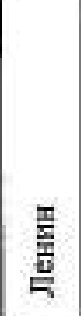 & 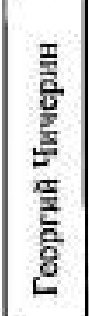 & 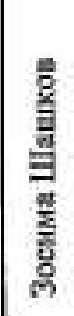 & 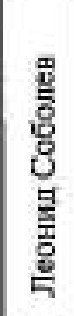 \\
\hline $\begin{array}{l}\text { 홈 } \\
\text { 음 } \\
\end{array}$ & 융 & 웅 & $\frac{8}{\circ}$ & $\begin{array}{l}\circ \\
\vdots \\
\text { ḋ }\end{array}$ & 今̊ & 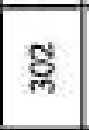 & ్ㅠ & ఫ్ల & 怘 & 욜 \\
\hline 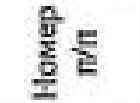 & $\bar{x}$ & $\mathcal{N}$ & 2 & से & $\approx$ & ฉึ & 고 & ๑̊ & तิ & ల్ల \\
\hline
\end{tabular}


है

\begin{tabular}{|c|c|c|c|c|c|c|c|c|c|c|}
\hline 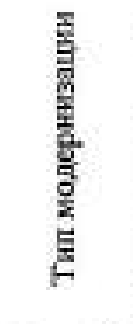 & 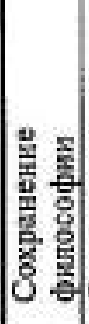 & 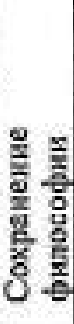 & 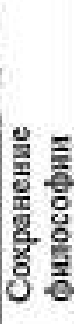 & 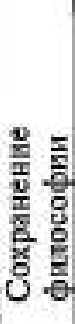 & 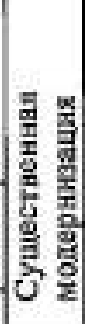 & 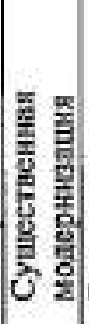 & 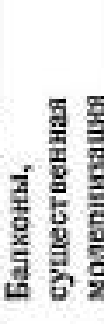 & 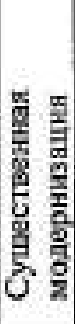 & 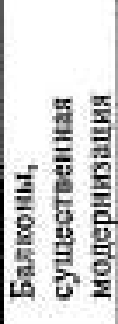 & 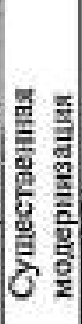 \\
\hline 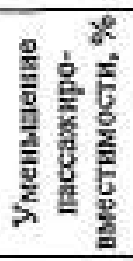 & 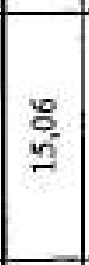 & $\stackrel{\$}{\stackrel{\infty}{\varrho}}$ & 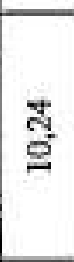 & F & 帛 & $\begin{array}{l}0 \\
\infty \\
\text { वै }\end{array}$ & $\begin{array}{l}\text { 点 } \\
\text { gु }\end{array}$ & 总 & ભ & 욜 \\
\hline 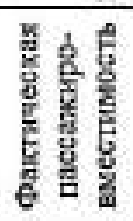 & જ్ & $\mathscr{g}$ & क्त & 売 & 参 & 요 & $\underset{\sim}{\mathbb{Z}}$ & $\stackrel{\ominus}{\sim}$ & ్ํㄱ & ఫ્ન \\
\hline 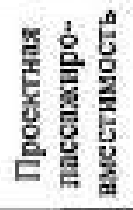 & ผู & लै & న్లె & ભึ & $\mathbb{m}^{2}$ & ह & 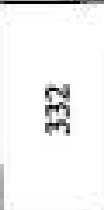 & సै & ్ㅐ & ల్ల \\
\hline 客产 & $\stackrel{2}{\circ}$ & 怘 & 吢 & 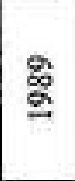 & $\stackrel{\mathbb{2}}{\cong}$ & $\bar{\S}$ & ळ & 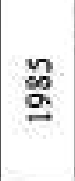 & $\stackrel{\text { a }}{\stackrel{\alpha}{\alpha}}$ & 总 \\
\hline 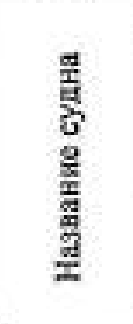 & 点 & 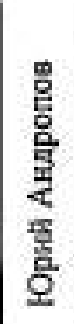 & 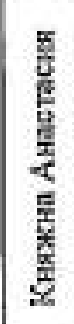 & 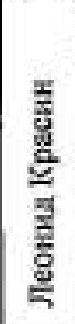 & 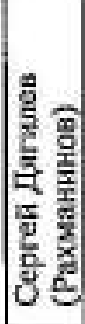 & 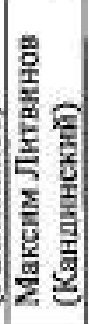 & 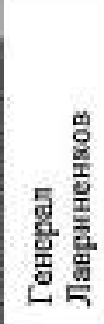 & 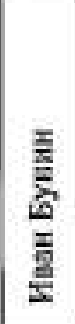 & 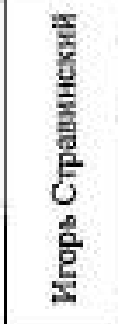 & 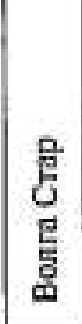 \\
\hline $\begin{array}{l}\text { 㔛 } \\
\text { 总 } \\
\end{array}$ & 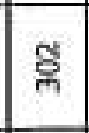 & छ్ల & ర్ల & 足 & ષ્ల & 胥 & 옹 & ઠิ & 일 & s్ల \\
\hline 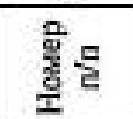 & हि & F & $\mathbb{m}$ & 昰 & 㘣 & n & ळ & F) & 190 & di \\
\hline
\end{tabular}


ВІСНИК

ОДЕСЬКОГО НАЦІОНАЛЬНОГО

МОРСЬКОГО УНІВЕРСИТЕТУ

№ 3 (60), 2019
HERALD

OF THE ODESSA NATIONAL

MARITIME UNIVERSITY № 3 (60), 2019

हैं

\begin{tabular}{|c|c|c|c|c|c|c|c|}
\hline 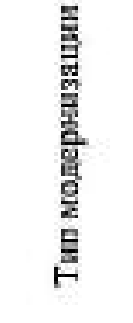 & 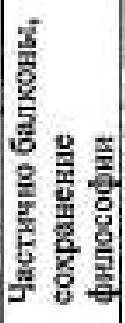 & 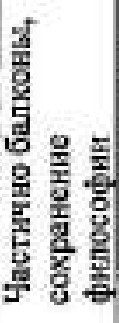 & 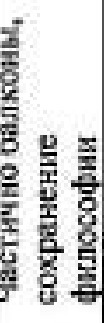 & 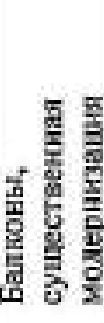 & 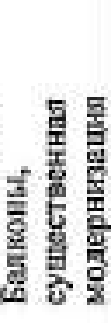 & 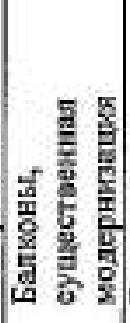 & 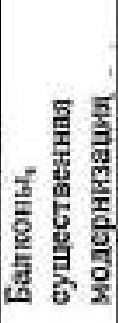 \\
\hline 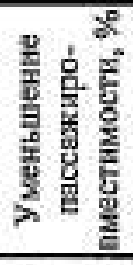 & $\frac{8}{4}$ & एँ & 资 & : & 尔 & ำ & $\frac{8}{\mathbb{d}}$ \\
\hline 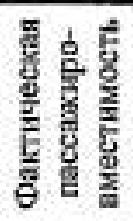 & भू & म্ & 号 & ฟึ & 品 & ฟึ & กิ \\
\hline 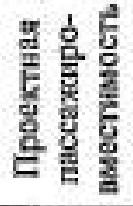 & శ్లె & ల్ల & $\approx$ & స్ల & ్ㅐㄱ & ल्ल & ల్లె \\
\hline 농 & $\stackrel{\text { \% }}{\stackrel{2}{二}}$ & $\begin{array}{l}\searrow \\
\cong\end{array}$ & $\begin{array}{l}\stackrel{\circ}{\varrho} \\
\stackrel{\circ}{2}\end{array}$ & 吕 & 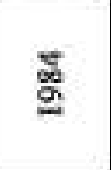 & $\begin{array}{l}\infty \\
\stackrel{2}{\varrho}\end{array}$ & $\stackrel{\infty}{\stackrel{2}{2}}$ \\
\hline 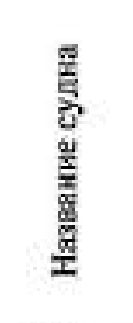 & 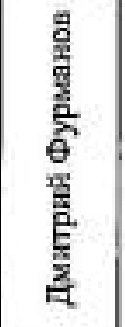 & 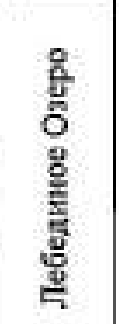 & 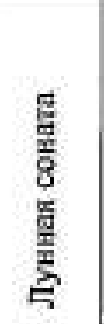 & 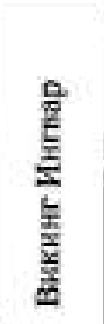 & 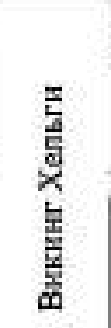 & 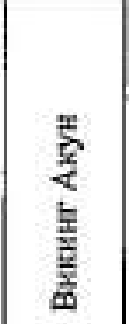 & 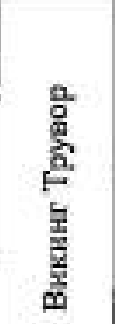 \\
\hline $\begin{array}{l}\text { 호 } \\
\text { 总 }\end{array}$ & 总 & ్ై & ర్ల & ర్ల & 总 & 8 & 일 \\
\hline $\begin{array}{l}\text { क्जि } \\
\text { 울 }\end{array}$ & $\bar{z}$ & ซู & m & J & $\frac{n}{8}$ & 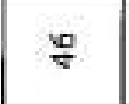 & f \\
\hline
\end{tabular}




\begin{tabular}{|c|c|c|c|c|c|c|c|c|}
\hline 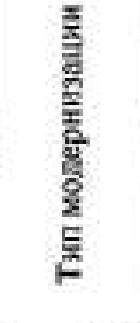 & 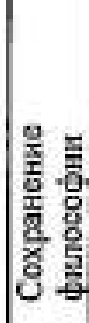 & 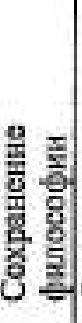 & 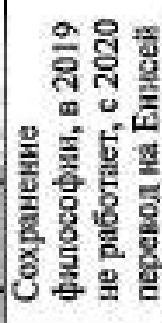 & 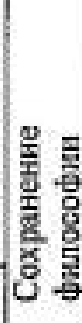 & 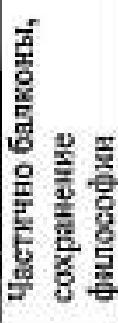 & 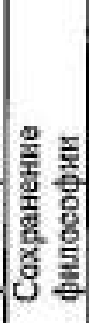 & 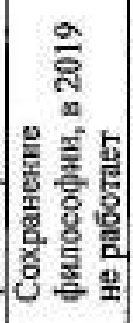 & 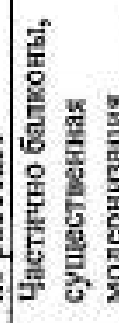 \\
\hline 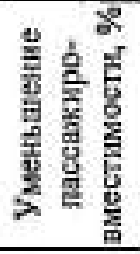 & $\underset{F}{E}$ & $\stackrel{\mathscr{D}}{\stackrel{2}{2}}$ & $\begin{array}{l}\stackrel{9}{\circ} \\
\text { m }\end{array}$ & $\begin{array}{l}\text { J } \\
\text { త }\end{array}$ & $\begin{array}{l}\text { a } \\
\text { ma }\end{array}$ & ๙ิ & $\begin{array}{l}\text { \& } \\
\text { of }\end{array}$ & $\begin{array}{l}\frac{7}{6} \\
\text { से }\end{array}$ \\
\hline 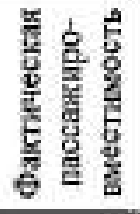 & 过 & $\stackrel{\circ}{\infty}$ & $\stackrel{\varnothing}{\rightleftharpoons}$ & 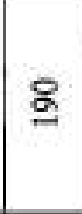 & $\stackrel{\circ}{\approx}$ & $\stackrel{\varnothing}{\nsim}$ & $\stackrel{\mathbb{2}}{\leftrightarrows}$ & ల్ల \\
\hline 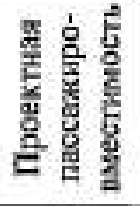 & ஜำ & $\stackrel{0}{\sim}$ & $\stackrel{\varpi}{\sim}$ & $\stackrel{\circ}{N}$ & $\stackrel{\infty}{d}$ & ฝे & นึ & 吕 \\
\hline 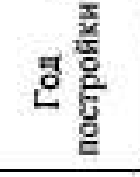 & g & $\stackrel{ \pm}{\mathrm{I}}$ & 冚 & $\stackrel{2}{\varrho}$ & $\stackrel{2}{g}$ & $\stackrel{\infty}{\stackrel{2}{\leftrightarrows}}$ & 点 & ま \\
\hline 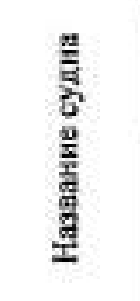 & 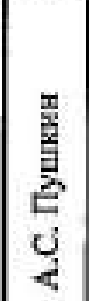 & 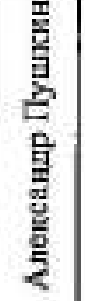 & 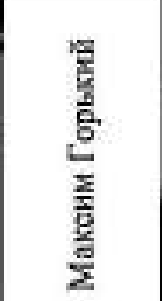 & 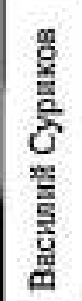 & $\frac{\frac{\pi}{E}}{\frac{\mathrm{E}}{\mathrm{E}}}$ & 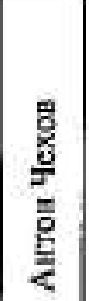 & 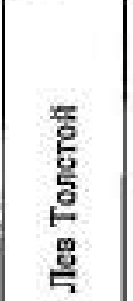 & 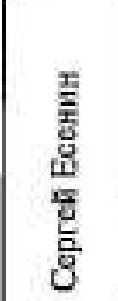 \\
\hline $\begin{array}{l}\frac{5}{8} \\
\text { 怘 } \\
\end{array}$ & స్ & $\frac{8}{2}$ & 웅 & 守 & 웅 & ڤั & $\underset{丶}{\grave{d}}$ & $\begin{array}{l}\text { 8. } \\
\text { d }\end{array}$ \\
\hline 올 & $\stackrel{\infty}{\forall}$ & 운 & পి & in & 동 & $\sqrt{3}$ & \& & $\approx$ \\
\hline
\end{tabular}




\begin{tabular}{|c|c|c|c|c|c|c|c|c|c|c|c|}
\hline 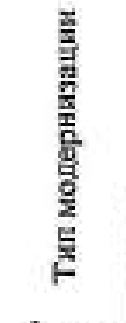 & 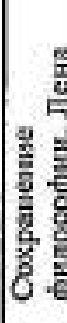 & 要 & $\begin{array}{l}0 \\
0 \\
0\end{array}$ & 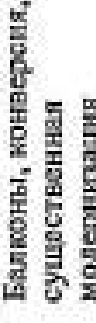 & 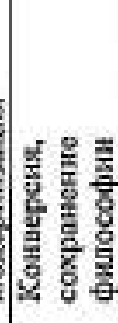 & 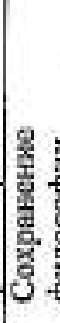 & & 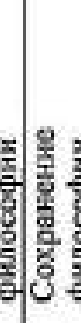 & 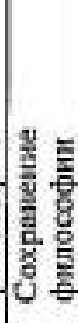 & 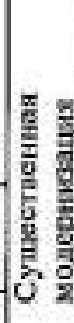 & 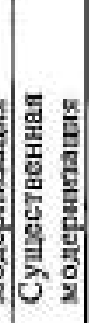 \\
\hline 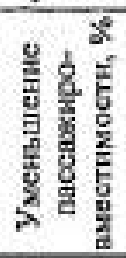 & $\begin{array}{l}6 \\
0 \\
0\end{array}$ & $\begin{array}{l}5 \\
0 \\
0\end{array}$ & हे & $\frac{n}{p}$ & $\frac{\infty}{d}$ & $\begin{array}{l}\sqrt{y} \\
0 \\
0\end{array}$ & \$ & 점 & $\begin{array}{l}\text { : } \\
\text { त्र }\end{array}$ & స్ & $\begin{array}{l}\text { p } \\
\text { ñ. }\end{array}$ \\
\hline 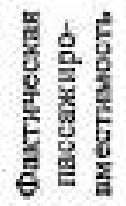 & $\stackrel{\circ}{\pi}$ & సิ & $\stackrel{\infty}{\circ}$ & 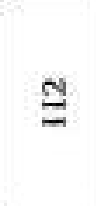 & $\stackrel{乛}{g}$ & ูั & ฟิ & ฟै & 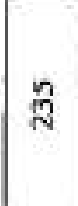 & $\stackrel{\circ}{2}$ & $\frac{q}{2}$ \\
\hline 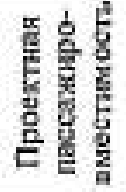 & ఖ્త్ & 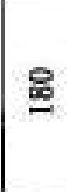 & $\underset{\beth}{ \pm}$ & Ф & 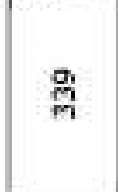 & స్ & $\frac{d}{m}$ & $\frac{\Im}{m}$ & $\frac{N}{n}$ & $\frac{d}{n}$ & 2 \\
\hline 몸 & $\stackrel{\text { }}{\stackrel{2}{2}}$ & $\mathscr{\mathscr { Z }}$ & $\stackrel{\Re}{\varrho}$ & $\frac{\mathrm{N}}{\bar{N}}$ & ำ & ूิ & 。 & 骂 & ఏே & $\begin{array}{l}\overrightarrow{8} \\
\stackrel{2}{g}\end{array}$ & 8 \\
\hline 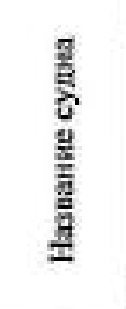 & 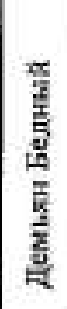 & 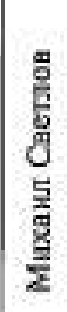 & 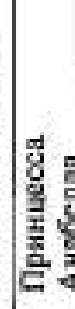 & 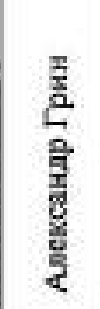 & 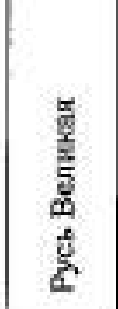 & 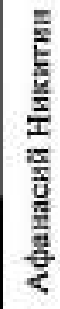 & 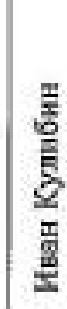 & 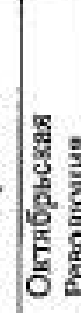 & 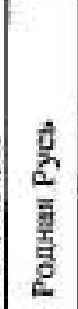 & 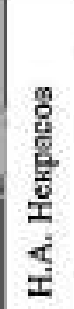 & हुّㅛ \\
\hline 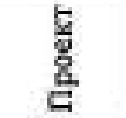 & $\begin{array}{l}n \\
\vdots \\
0\end{array}$ & d & 吅 & ? & 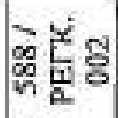 & 离 & है & 客 & के & 豙 & .7 \\
\hline 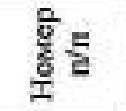 & ஜ̊ & nิ & 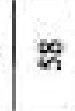 & झे & 8 & $\overrightarrow{6}$ & 8 & 8 & 芯 & : & 8 \\
\hline
\end{tabular}




\begin{tabular}{|c|c|c|c|c|c|c|c|c|c|c|}
\hline 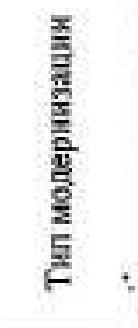 & 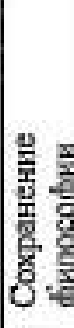 & & & 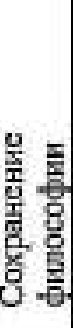 & 帝 & 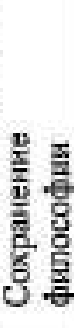 & & $\begin{array}{l}0 \\
8 \\
8\end{array}$ & & 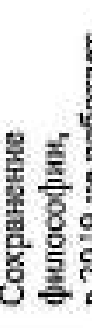 \\
\hline 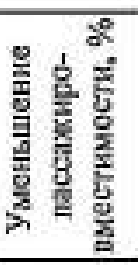 & 舫 & ํ․ & बूँ & $\frac{\mathscr{2}}{2}$ & ผี & हूँ & 总 & 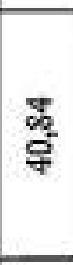 & $\begin{array}{l}{ }_{0}^{\circ} \\
\text { of } \\
\text { of }\end{array}$ & \&్ల \\
\hline 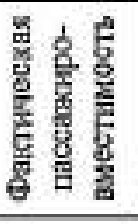 & $\stackrel{9}{9}$ & 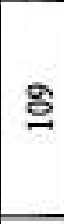 & $\stackrel{\Xi}{N}$ & สี & $\stackrel{9}{9}$ & $\stackrel{\infty}{\underline{y}}$ & 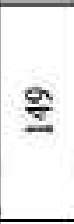 & 疋 & 总 & $\frac{n}{N}$ \\
\hline 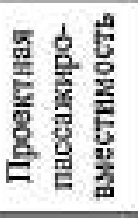 & ल) & 글 & $\frac{N}{m}$ & 길 & $\frac{\mathrm{d}}{\mathrm{m}}$ & $\bar{m}$ & $\bar{m}$ & $\bar{m}$ & $\bar{m}$ & $\vec{m}$ \\
\hline 한 & $\stackrel{\Xi}{\leftrightarrows}$ & 용 & $\stackrel{\circ}{\circ}$ & ङ & $\overrightarrow{\mathrm{g}}$ & 总 & ळ & 。 & $\stackrel{\Xi}{\leftrightarrows}$ & ఫ్ \\
\hline 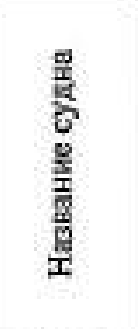 & 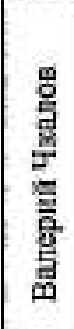 & 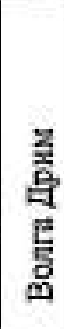 & 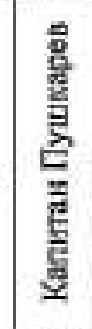 & 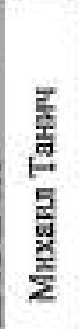 & $\begin{array}{l}\text { 点 } \\
\text { 量 } \\
\text { 总 }\end{array}$ & 商 & 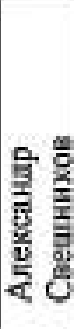 & 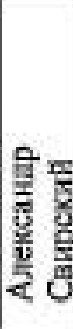 & 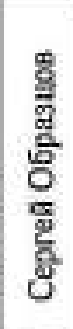 & 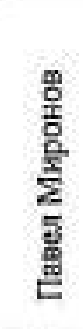 \\
\hline$\frac{5}{\frac{5}{8}}$ & $\begin{array}{l}\text { के } \\
\text { के } \\
\end{array}$ & 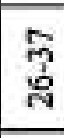 & $\begin{array}{l}\text { Es } \\
\text { के } \\
\text { त् }\end{array}$ & 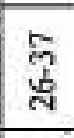 & $\begin{array}{l}\text { ⿳े口े } \\
\text { s. }\end{array}$ & 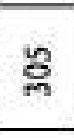 & : & 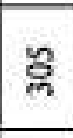 & 哭 & 足 \\
\hline 홀들 & 5 & $\ddot{\circ}$ & is & $\therefore$ & $\vec{F}$ & $\mathbb{N}$ & 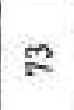 & $\Sigma$ & 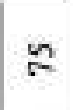 & $\because$ \\
\hline
\end{tabular}




\begin{tabular}{|c|c|c|c|c|c|c|c|c|c|c|c|}
\hline 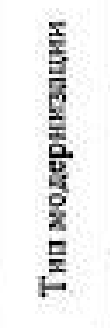 & 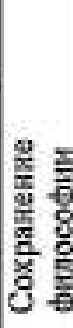 & 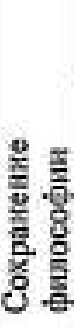 & 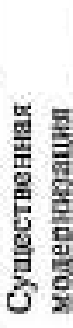 & 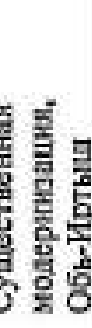 & 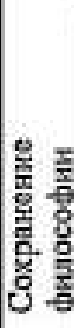 & 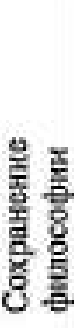 & 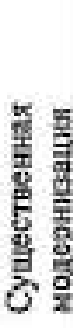 & 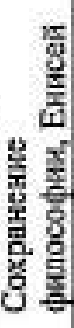 & 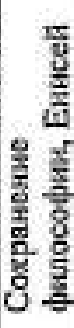 & & 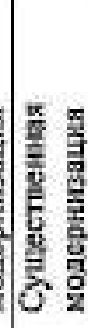 \\
\hline 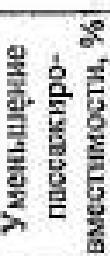 & 学 & 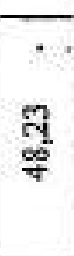 & 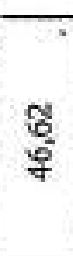 & $\begin{array}{l}\text { \& } \\
\text { d }\end{array}$ & 莳 & है & $\overline{3}$ & $\frac{\mathcal{M}}{\mathrm{m}}$ & $\frac{\text { च }}{m}$ & $\frac{b}{n}$ & $\begin{array}{l}2 \\
0 \\
0 \\
*\end{array}$ \\
\hline 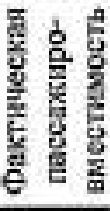 & 9 & $\Phi$ & $\cong$ & in & 2 & స్త్ & $\stackrel{\circ}{\pi}$ & 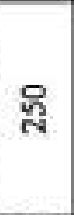 & 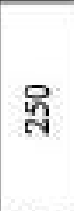 & $\cong$ & 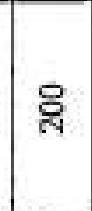 \\
\hline 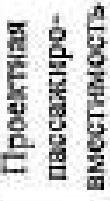 & $\vec{m}$ & $\vec{m}$ & $\approx$ & 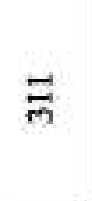 & $\overrightarrow{\mathrm{m}}$ & $\overrightarrow{\vec{m}}$ & 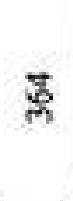 & 胥 & 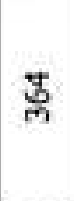 & ఫ્ల & 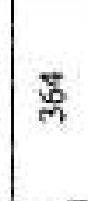 \\
\hline 墪 & $\overrightarrow{\mathrm{g}}$ & $\nsubseteq$ & 总 & 莺 & $\overrightarrow{\mathrm{g}}$ & ฐ & 气 & 总 & 志 & 莺 & 气 \\
\hline 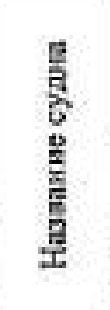 & 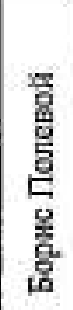 & 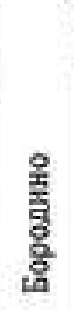 & 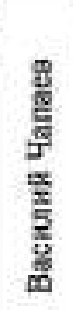 & 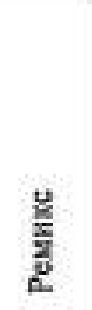 & 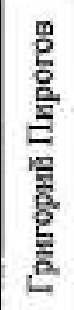 & 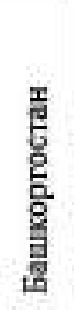 & $\begin{array}{l}\text { है } \\
\frac{5}{5} \\
\frac{5}{a} \\
\vdots \\
\vdots\end{array}$ & $\begin{array}{l}\frac{8}{8} \\
\stackrel{5}{E} \\
\frac{1}{2} \\
<\end{array}$ & 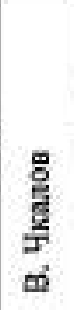 & 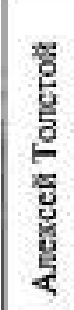 & 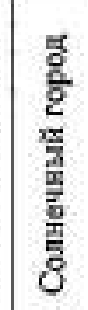 \\
\hline $\begin{array}{l}\text { to } \\
\text { 总 }\end{array}$ & 足 & ષ્ల & 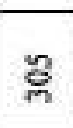 & 足 & 总 & 足 & 离 & $\stackrel{\infty}{\aleph}$ & 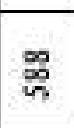 & 总 & $\begin{array}{l}\infty \\
\infty \\
\aleph\end{array}$ \\
\hline 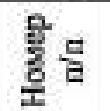 & $E$ & 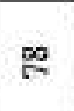 & 2 & \& & $\bar{\infty}$ & $\infty$ & 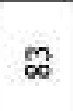 & \pm & $\approx$ & ஜ & $\infty$ \\
\hline
\end{tabular}


ВІСНИК

ОДЕСЬКОГО НАЦІОНАЛЬНОГО

МОРСЬКОГО УНІВЕРСИТЕТУ

№ 3 (60), 2019
HERALD

OF THE ODESSA NATIONAL MARITIME UNIVERSITY № 3 (60), 2019

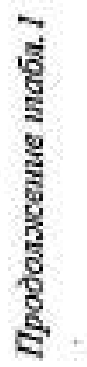

\begin{tabular}{|c|c|c|c|c|c|c|c|c|c|c|c|}
\hline 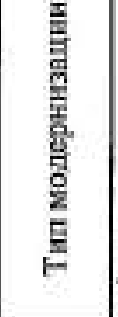 & 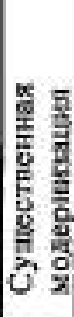 & 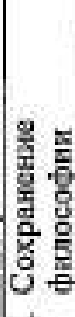 & 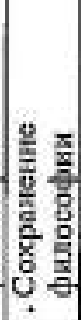 & 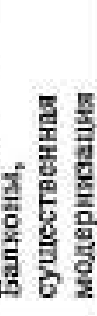 & 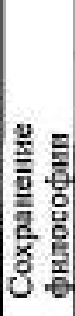 & 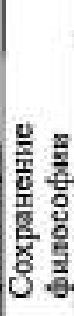 & 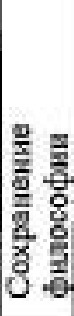 & 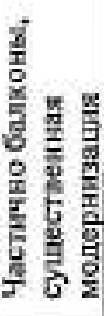 & 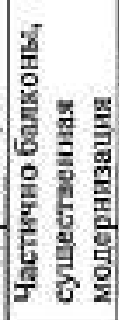 & 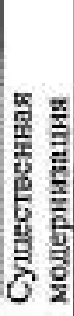 & \\
\hline 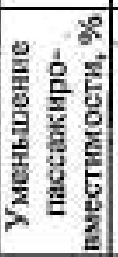 & $\begin{array}{l}2 \\
\text { के } \\
\text { की }\end{array}$ & $\begin{array}{l}. \\
\text { फू } \\
\text { कू }\end{array}$ & $\frac{\pi}{5}$ & 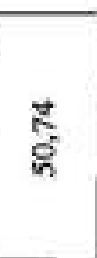 & $\begin{array}{l}\circ \\
\text { के } \\
\text { के }\end{array}$ & 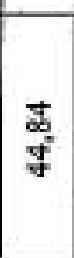 & है & $\frac{n}{n}$ & $\begin{array}{l}\text { \&્ळ } \\
\text { N่̂ }\end{array}$ & $\frac{\infty}{\sigma^{2}}$ & \\
\hline 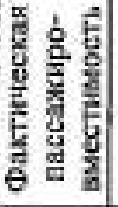 & : & สి & ฐ & 홍 & ฆี & 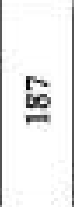 & तึ & 号 & 8 & $\stackrel{2}{2}$ & \\
\hline 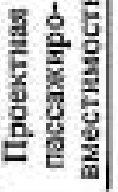 & 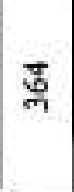 & 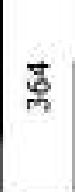 & ब్ & भิ & लू & 量 & ले & ले & 舋 & लू & \\
\hline 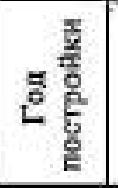 & 吼 & ڤ̊ & 5 & $\vec{\Xi}$ & ติ & 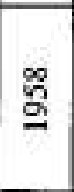 & ఏ & ฐ & Ð & 气 & \\
\hline 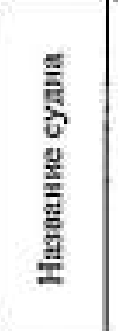 & $\begin{array}{l}\text { 幕 } \\
\text { 鸹 }\end{array}$ & 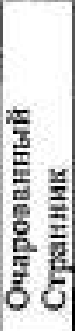 & 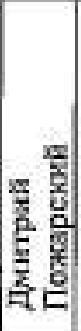 & 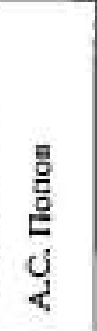 & 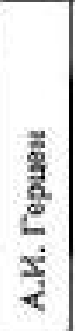 & 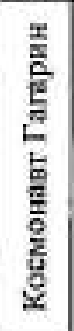 & 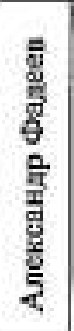 & 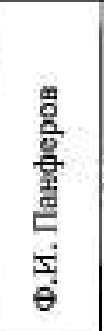 & 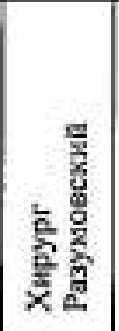 & 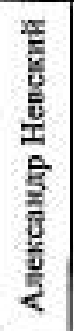 & $\exists$ \\
\hline 홈 & $\underset{n}{\circ}$ & $\underset{\infty}{\infty}$ & $\underset{\sharp}{\infty}$ & 象 & 㤎 & $\underset{2}{* 0}$ & 吕 & 荄 & 象 & $\stackrel{\infty}{*}$ & 86 \\
\hline 물형 & $\mathscr{\infty}$ & வ & \& & $\approx$ & 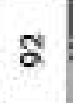 & $\stackrel{m}{\alpha}$ & ま & 2 & $\stackrel{\circ}{\circ}$ & $\mathrm{s}$ & \\
\hline
\end{tabular}




\begin{tabular}{|c|c|c|c|c|c|c|c|c|c|c|c|}
\hline 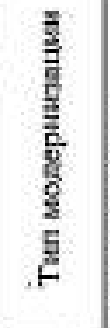 & 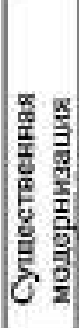 & & & & $\mid \begin{array}{ll}0 \\
5\end{array}$ & $\frac{10}{6}$ & 3 & 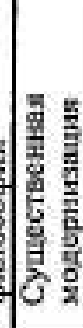 & 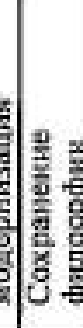 & 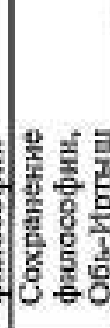 & 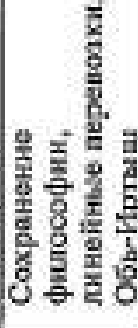 \\
\hline 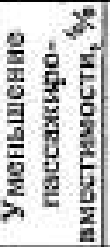 & $\frac{\circ}{5}$ & สุ & $\begin{array}{l}\mathscr{m} \\
\stackrel{\mathscr{N}}{N}\end{array}$ & 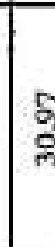 & $\frac{9}{x}$ & $\frac{\mathrm{g}}{\mathrm{m}}$ & $\stackrel{\mathscr{g}}{\mathbb{d}}$ & $\begin{array}{l}0 \\
\text { 足 } \\
\text { t. }\end{array}$ & $\begin{array}{l}\text { ga } \\
\text { a }\end{array}$ & 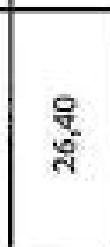 & ๕. \\
\hline 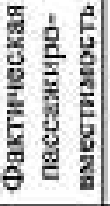 & $\cong$ & 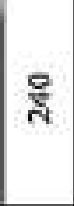 & हू & $\not$ & ส๊ & กี & శ్ & 8 & ฐ్తి & $y$ & బ్ \\
\hline 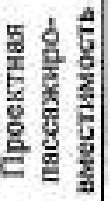 & 2 & ì & 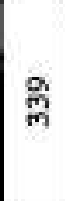 & $\stackrel{m}{m}$ & हे & ले & ले & के & $\$$ & g & $\Xi$ \\
\hline 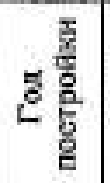 & 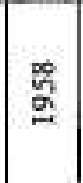 & 兽 & ‡ & $g$ & gh & : & ฏू & $\stackrel{5}{g}$ & ફ & ڤે & $\stackrel{\varkappa}{\Omega}$ \\
\hline 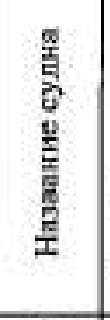 & 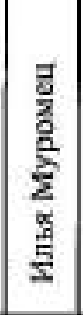 & 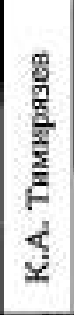 & 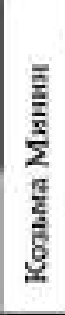 & 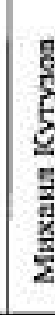 & $\begin{array}{l}\overrightarrow{8} \\
\stackrel{\infty}{0} \\
\dot{\varphi}\end{array}$ & 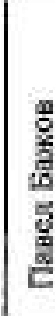 & $\frac{5}{2}$ & $\begin{array}{l}\frac{2}{0} \\
\frac{5}{5} \\
\frac{25}{8} \\
\frac{5}{8}\end{array}$ & 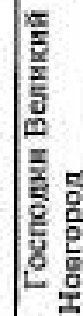 & 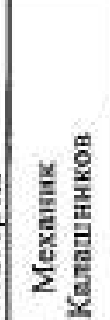 & 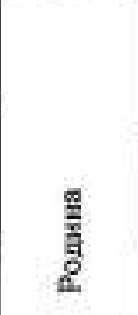 \\
\hline $\begin{array}{l}\frac{t}{8} \\
\frac{8}{E}\end{array}$ & 冓 & $\stackrel{\infty}{\%}$ & 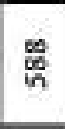 & 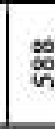 & $\stackrel{\infty}{\sharp}$ & $\begin{array}{l}\infty \\
\$ \\
\varpi\end{array}$ & 密 & 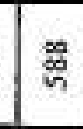 & 过 & हैं & हैं \\
\hline 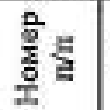 & 2 & $\stackrel{8}{\stackrel{2}{2}}$ & $\Xi$ & 응 & $\stackrel{2}{=}$ & 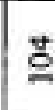 & $\stackrel{n}{\underline{9}}$ & $\stackrel{8}{8}$ & 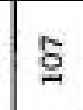 & $\stackrel{\infty}{\stackrel{0}{\circ}}$ & 8 \\
\hline
\end{tabular}


ВІСНИК

ОДЕСЬКОГО НАЦІОНАЛЬНОГО

МОРСЬКОГО УНІВЕРСИТЕТУ

№ 3 (60), 2019
HERALD

OF THE ODESSA NATIONAL

MARITIME UNIVERSITY

产

\begin{tabular}{|c|c|c|c|c|c|c|c|c|c|}
\hline 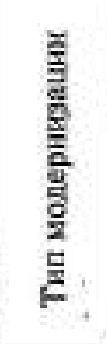 & 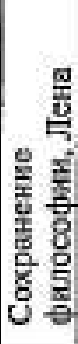 & 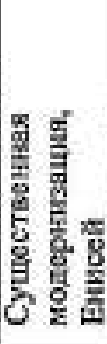 & 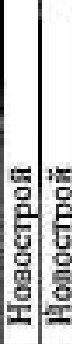 & 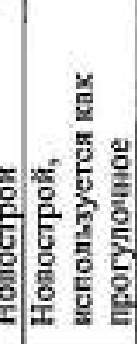 & 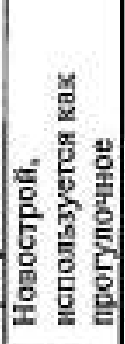 & 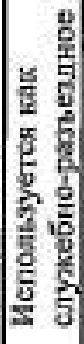 & 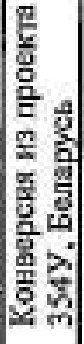 & 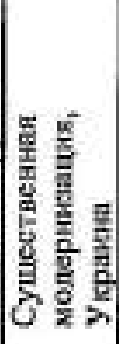 & 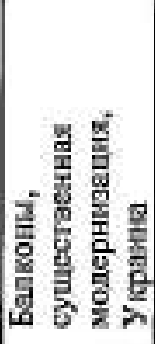 \\
\hline 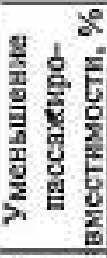 & $\begin{array}{l}\text { तy } \\
y\end{array}$ & $\frac{n}{n}$ & & & & & & mे & $\begin{array}{l}\text { शे } \\
\text { के }\end{array}$ \\
\hline 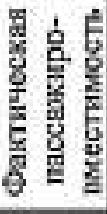 & 8 & ถి & লি & 요 & ్ㅗ & $y$ & $\stackrel{ల}{~}$ & 是 & g \\
\hline 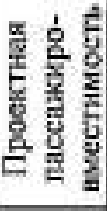 & $\stackrel{5}{2}$ & $\stackrel{2}{2}$ & & & & & & 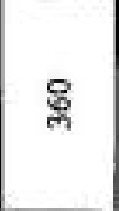 & 胥 \\
\hline 息喜 & ̌ㅡㅁ & ฆั & 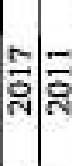 & 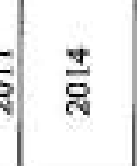 & 윰 & $\frac{m}{2}$ & ๙ூ & $\stackrel{\circ}{\stackrel{\circ}{2}}$ & 巢 \\
\hline 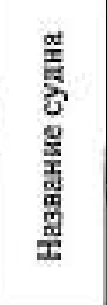 & 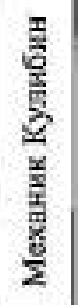 & 㕿 & 占点点 & 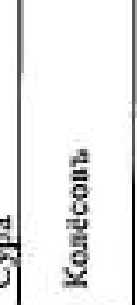 & 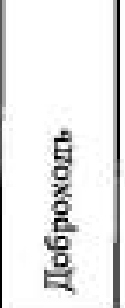 & $\frac{\mathrm{x}}{8}$ & $\frac{\text { है }}{\text { है }}$ & 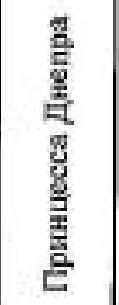 & 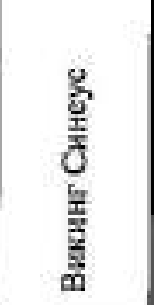 \\
\hline $\begin{array}{l}\frac{t}{0} \\
\frac{8}{2} \\
\end{array}$ & 过 & $\frac{\vec{b}}{6}$ & 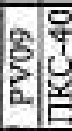 & 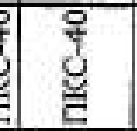 & 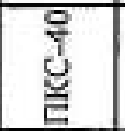 & $\underset{D}{\mathbb{d e}}$ & $\stackrel{\infty}{\varrho}$ & 㕆 & 류 \\
\hline$\frac{\text { fô }}{2}$ & $\stackrel{9}{=}$ & $\Xi$ & $=$ & + & $\neq$ & $*$ & $*$ & $\rightarrow$ & $*$ \\
\hline
\end{tabular}


ВІСНИК

ОДЕСЬКОГО НАЦІОНАЛЬНОГО

МОРСЬКОГО УНІВЕРСИТЕТУ

№ 3 (60), 2019
HERALD

OF THE ODESSA NATIONAL

MARITIME UNIVERSITY № $3(60), 2019$

При этом на 12 круизных пассажирских судах (10,8 \% от всех работающих) были установлены балконы на всех палубах, на 9 судах балконы установлены частично (для определенной категории номеров, чаще всего, для кают класса «Люкс»).

Работы по модернизации и переоборудованию продолжаются. За крайние пять лет было модернизировано 34 судна (32 в России плюс два днепровских судна проекта 301).

Например, на рынок вышла швейцарская компания Thurgau Travel [10], для которой в межнавигационный период 2018-2019 годов были модернизированы сразу 2 РКПС, в том числе теплоход «А.С. Попов» («Thurgau Karelia») - первое судно проекта 588 с балконами не только для кают класса «Люкс».

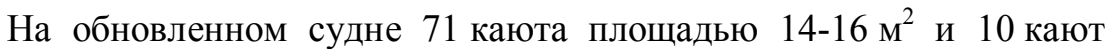
площадью 11-14 м², при этом количество пассажиров сократилось до 162 с 339 человек (на 52,2 \%).

По внутренней классификации оператора судно категории $3+*$ (см. рисунок 1).

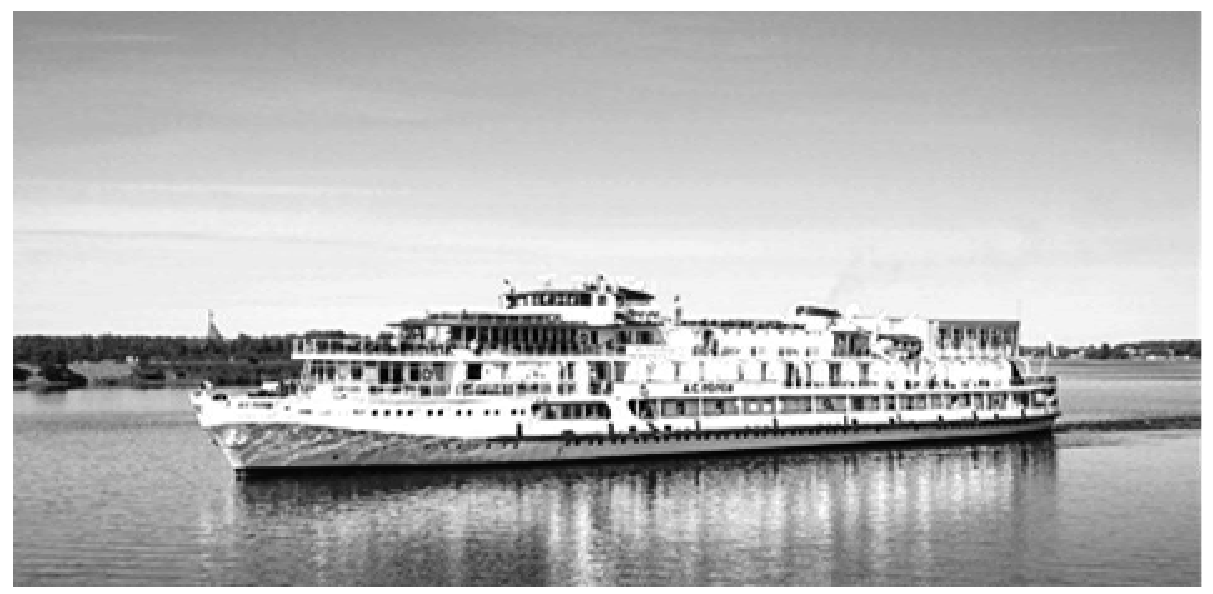

Рис. 1. Общий вид m/x «А.С. Попов» после модернизащии 2018-2019 года. Автор фотографии Александр Конов [11]

Второй - теплоход «Ремикс» («Remix») - судно проекта 305 для работы на линии Салехард - Новосибирск (река Обь). На обновленном судне каюты площадью от 10 до $60 \mathrm{~m}^{2}$, количество пассажиров сократилось до 53 с 311 человек (на 83\%). По внутренней классификации оператора судно категории $3 *$ (см. рисунок 2 ). 
ВІСНИК

ОДЕСЬКОГО НАЦІОНАЛЬНОГО

МОРСЬКОГО УНІВЕРСИТЕТУ

№ 3 (60), 2019
HERALD

OF THE ODESSA NATIONAL

MARITIME UNIVERSITY № 3 (60), 2019

Рис. 2. Общий вид $m / x$ «Ремикс» после модернизачии 2018-2019 года. Автор фотографии Алексей Потелещенко [11]

Таблий 2

Данные по модернизачиям активных речных круизных пассажирских судов на навигаџию 2019 года

\begin{tabular}{|c|c|c|c|c|c|c|c|}
\hline \multirow{2}{*}{ Проект } & \multicolumn{2}{|c|}{$\begin{array}{c}\text { Сохранение } \\
\text { философии }\end{array}$} & \multicolumn{3}{|c|}{ Существенная модернизация } & \multirow{2}{*}{$\begin{array}{c}\text { Модерни- } \\
\text { зация } \\
\text { в 2008- } \\
2013\end{array}$} & \multirow{2}{*}{\begin{tabular}{|c|} 
Модерни- \\
зация \\
в 2014- \\
2019
\end{tabular}} \\
\hline & \begin{tabular}{|c|} 
без \\
балконов
\end{tabular} & $\begin{array}{l}\text { частично } \\
\text { балконы }\end{array}$ & $\begin{array}{c}\text { без } \\
\text { балконов }\end{array}$ & $\begin{array}{l}\text { частично } \\
\text { балконы }\end{array}$ & балконы & & \\
\hline 301 & 7 & 1 & 7 & 0 & 3 & 3 & 8 \\
\hline $92-016$ & 6 & 0 & 0 & 0 & 1 & 1 & 0 \\
\hline 302 & 10 & 3 & 4 & 0 & 6 & 6 & 8 \\
\hline Q-040 & 3 & 1 & 0 & 0 & 0 & 0 & 2 \\
\hline \begin{tabular}{|l|} 
Q-056 \\
\end{tabular} & 2 & 0 & 0 & 0 & 0 & 0 & 1 \\
\hline Q-065 & 2 & 0 & 0 & 1 & 0 & 0 & 1 \\
\hline 463 & 1 & 0 & 0 & 0 & 0 & 0 & 0 \\
\hline $\begin{array}{l}\text { 588/РЕГК } \\
\text { (конверсия) }\end{array}$ & 1 & 0 & 0 & 0 & 0 & 1 & 0 \\
\hline \begin{tabular}{|l} 
PV08 \\
(конверсия)
\end{tabular} & 0 & 0 & 0 & 0 & 1 & 1 & 0 \\
\hline $26-37$ & 7 & 0 & 4 & 0 & 0 & 3 & 1 \\
\hline 305 & 8 & 0 & 3 & 0 & 0 & 1 & 3 \\
\hline 588 & 12 & 0 & 8 & 3 & 1 & 3 & 7 \\
\hline 646 & 4 & 0 & 1 & 0 & 0 & 0 & 1 \\
\hline \begin{tabular}{|l|} 
PV09 \\
\end{tabular} & - & - & - & - & - & - & - \\
\hline ПКС-40 & - & - & - & - & - & - & - \\
\hline 301 (Днепр) & 0 & 0 & 1 & 0 & 1 & 0 & 2 \\
\hline Суммарно & 63 & 5 & 28 & 4 & 13 & 19 & 34 \\
\hline \multirow{2}{*}{\begin{tabular}{|l|} 
Суммарно \\
без Днепра
\end{tabular}} & 63 & 5 & 27 & 4 & 12 & \multirow[t]{2}{*}{19} & \multirow[t]{2}{*}{32} \\
\hline & & 68 & & 43 & & & \\
\hline
\end{tabular}


ВІСНИК

ОДЕСЬКОГО НАЦІОНАЛЬНОГО

МОРСЬКОГО УНІВЕРСИТЕТУ

№ 3 (60), 2019
HERALD

OF THE ODESSA NATIONAL

MARITIME UNIVERSITY № 3 (60), 2019

Помимо компании Thurgau Travel в межнавигационный период 2018-2019 года активно работали над повышением комфортабельности компании «ВодоходЂ» (т/x «Нижний Новгород» и т/x «СанктПетербург» - см. рисунок 3), «Мостурфлот» (т/х «Сергей Есенин», т/x «А.С. Пушкин», т/х «Россия» - см. рисунок 4), «Инфофлот» (т/х «Василий Чапаев», т/х «Северная сказка»), «Донинтурфлот» (т/х «Игорь Стравинский») и «Белый лебедь» (т/х «Бородино», т/x «К.А. Тимирязев»).

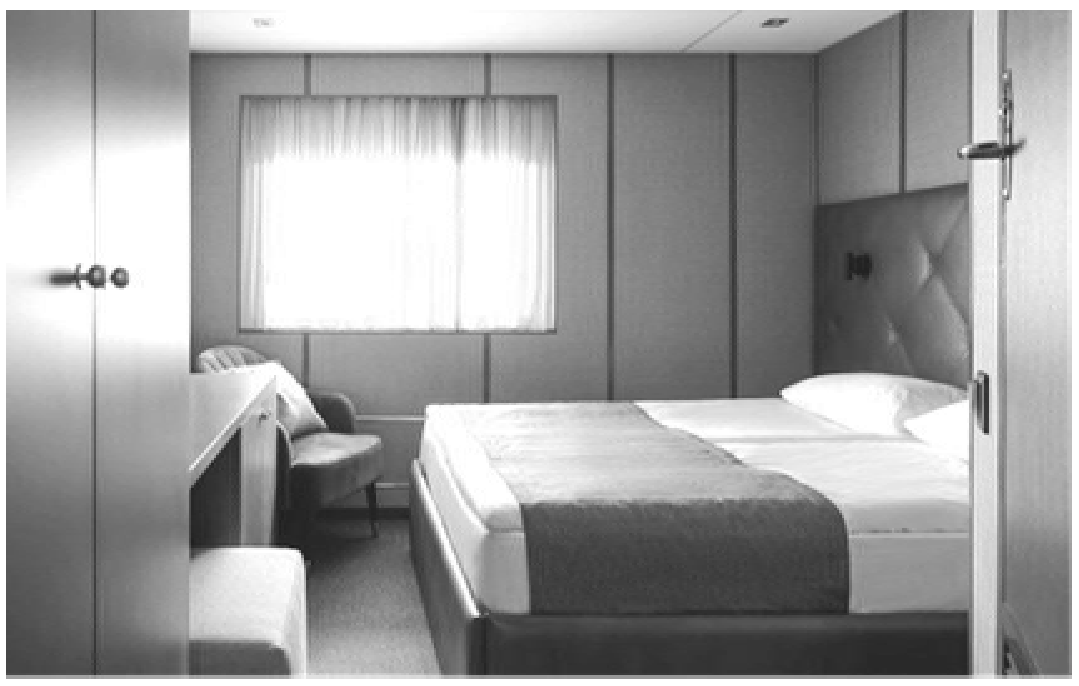

Рис. 3. Каюта класса «Делюкс» на обновленном $m / x$ «Санкт-Петербург» [5]

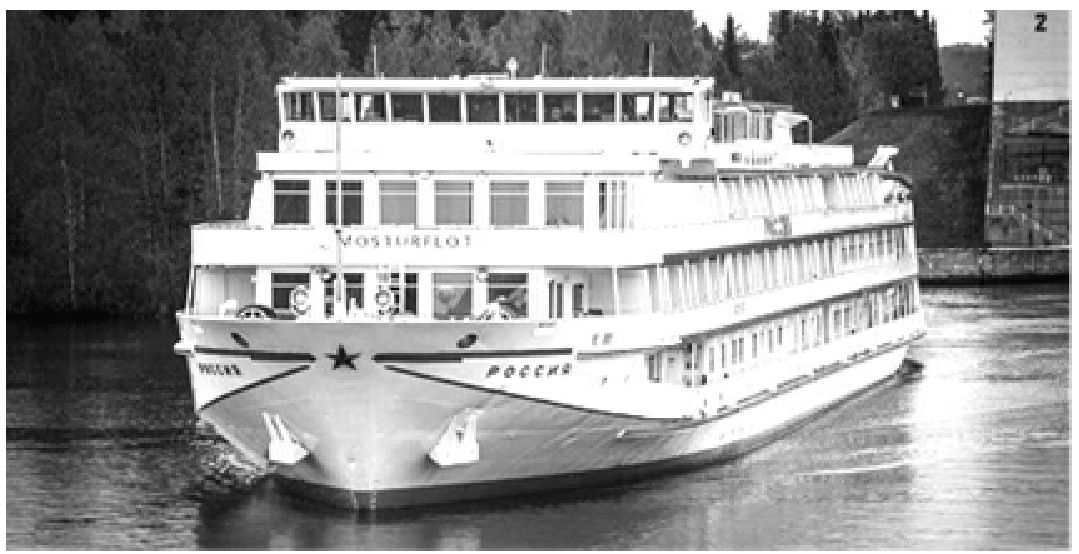

Рис. 4. Общий вид $m / x$ «Россия» после модернизачии 2018-2019 года. Автор фотографии Владимир Владиславлев [11] 
ВІСНИК

ОДЕСЬКОГО НАЦІОНАЛЬНОГО

МОРСЬКОГО УНІВЕРСИТЕТУ

№ 3 (60), 2019
HERALD

OF THE ODESSA NATIONAL

MARITIME UNIVERSITY

№ $3(60), 2019$

Автором была выполнена также средняя оценка влияния модернизации на пассажировместимость речных круизных пассажирских судов.

Для этого все активные РКПС были сгруппированы в две группы.

Первая (суда проектов 26-37, 588, 305, 646) - это грузопассажирские и пассажирские суда для дальних линий, построенные с начала $50-x$ до середины 60-х годов прошлого столетия.

Вторая группа судов (проекты 301, 302, Q-040, Q-056, Q-065, 92-016) - это суда, которые строились в 70-90-е годы, причем многие уже с учетом круизной функции [9].

При существенной модернизации РКПС из первой группы пассажировместимость в среднем уменьшается на 52,3 \%, при сохранении философии - на $32 \%$.

При существенной модернизации РКПС из второй группы - на 37 \%, при сохранении философии - на 16,1\%.

В таблице 3 рассчитана общая пассажировместимость работающих в 2019 году речных круизных пассажирских судов, определен средний возраст работающих судов, а также, используя данные исследований авторов [9], даны прогнозы по пассажировместимости на среднесрочную перспективу до 2030 года (см. рисунок 5).

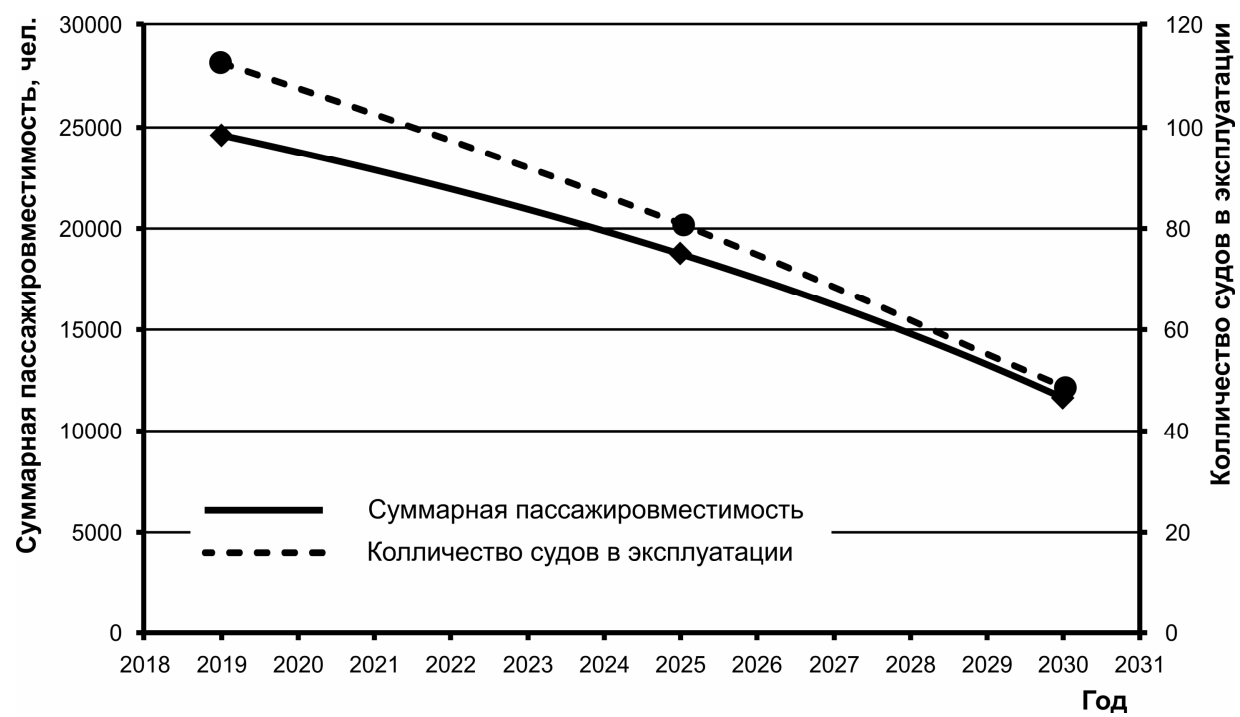

Рис. 5. Прогноз по общей пассажсировместимости активных РКПС

Общая пассажировместимость на 2019 год составляет 24602 человека. 


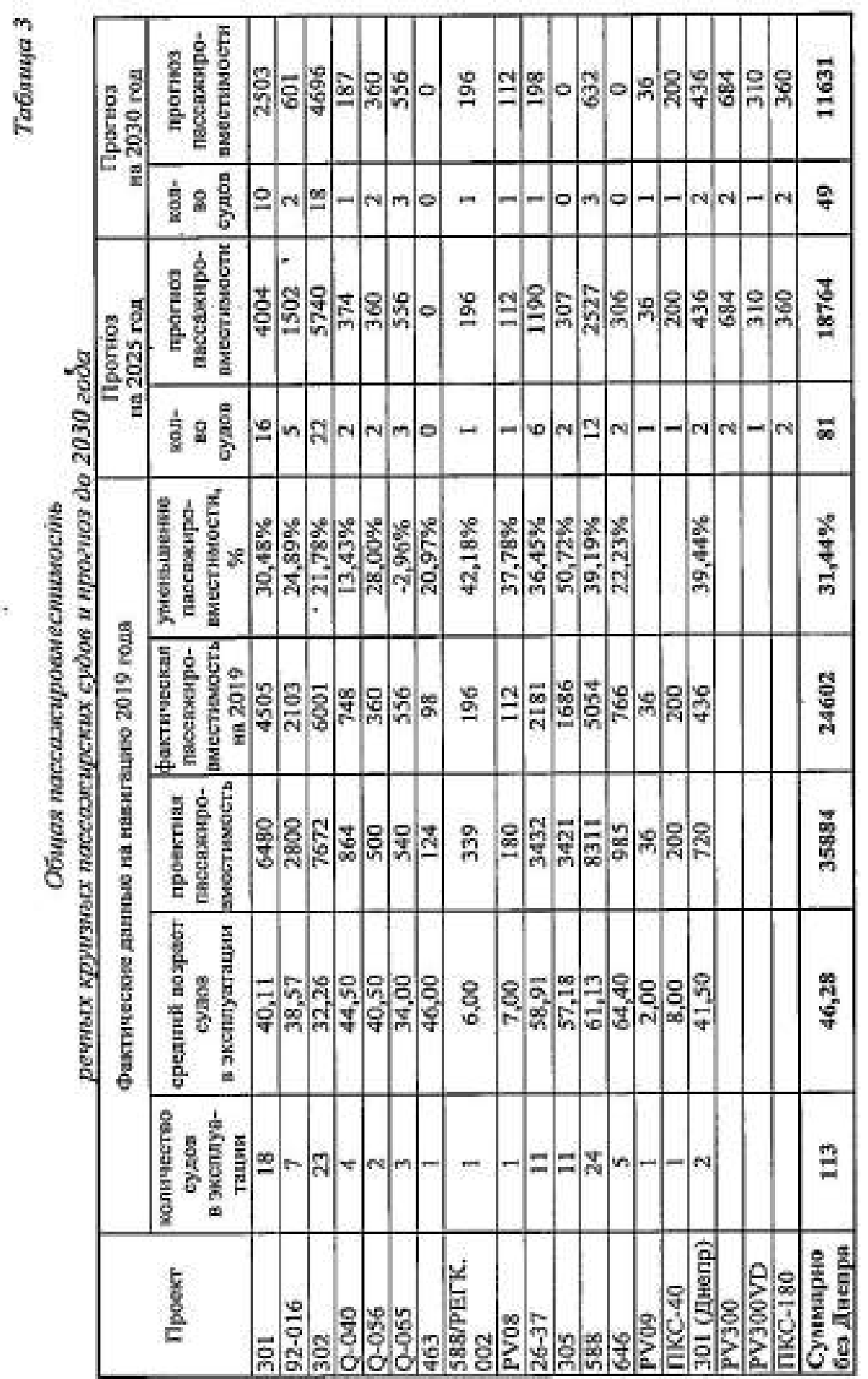


ВІСНИК

ОДЕСЬКОГО НАЦІОНАЛЬНОГО

МОРСЬКОГО УНІВЕРСИТЕТУ

№ 3 (60), 2019
HERALD

OF THE ODESSA NATIONAL

MARITIME UNIVERSITY № 3 (60), 2019

К 2030 году прогнозируется уменьшение пассажировместимости на 52,72\% до 11631 человека, и это, не считая возможного уменьшения пассажировместимости за счет глубокой модернизации существующих круизных судов для повышения уровня комфортабельности в 20192030 годы.

При этом также не учитываются возможные новые РКПС, которые будут заказаны и построены (либо переоборудованы из других типов судов), начиная с 2020 года.

Общая пассажировместимость на 2019 год составляет 24602 человека.

К 2030 году прогнозируется уменьшение пассажировместимости на 52,72\% до 11631 человека, и это, не считая возможного уменьшения пассажировместимости за счет глубокой модернизации существующих круизных судов для повышения уровня комфортабельности в 20192030 годы.

При этом также не учитываются возможные новые РКПС, которые будут заказаны и построены (либо переоборудованы из других типов судов), начиная с 2020 года.

Заключение. Выполненное в работе исследование показало, что общая пассажировместимость РКПС снизится до 11631 человека (на $52,72 \%$ к к 2030 году, и это, не считая возможного уменьшения пассажировместимости за счет будущих модернизационных работ.

Для сохранения понятия «речной круиз», и не только для иностранных туристов, рекомендуется на среднесрочную и долгосрочную перспективы строительство новых пассажирских судов, которые бы наиболее полно удовлетворяли запросам рынка. Это могут быть круизные пассажирские суда как для классических речных маршрутов в европейской части страны (PV300, PV500VB, PV09, ПКС-180 и т.п.), так и смешанного плавания суда для работы в прибрежных морях и на речных маршрутах, в том числе, на Енисее, Лене, Оби и Амуре (PV300VD, PV11 и т.п.).

\section{СПИСОК ЛІТЕРАТУРИ}

1. Егоров Г.В., Егоров А.Г., Калугин Я.В. Практическая реализациия концептов современных круизных судов смешанного плавания // Материаль Х междн. научно-техн. конф. "Инновачии в судостроении и океанотехнике». Николаев: НУК, 2019. C. $106-109$.

2. Егоров А.Г. Принципь проектирования речных круизных судов с использованием судов-доноров // Морской Вестник. 2019. № 3 (71). C. 9-15. 
ВІСНИК

ОДЕСЬКОГО НАЦІОНАЛЬНОГО

МОРСЬКОГО УНІВЕРСИТЕТУ

№ 3 (60), 2019
HERALD

OF THE ODESSA NATIONAL

MARITIME UNIVERSITY

3. Егоров А.Г. Анализ отечественного опыта переоборудования круизных пассажирских судов // Морской Вестник. 2019. № 2 (70). C. 9-14.

4. Егоров А.Г. Речные круизные пассажсирские суда: инновачионные решения и их применимость при конверсии // Вестник OHМУ.Oдесcа: OHMУ, 2018. Bbin.4 (57). C. 23-52.

5. Сайт компании «ВодоходЬ» [Электронный ресурс]. URL: https://vodohod.com/cruises/life/health/ (дата обращчения 28.10.2019).

6. Сайт компании «Мостурфлот» [Электронный ресурс]. URL: https://www.mosturflot.ru/post?id=29188 (дата обращения 28.10.2019).

7. Сайт компании «Мостурфлот» [Электронный ресурс]. URL: https://www.mosturflot.ru/post?id=29348 (дата обращения 28.10.2019).

8. Сайт компании «Инфофлот» [Электронный ресурс]. URL: https://www.infoflot.com/news/new7980/ (дата обращения 28.10.2019).

9. Егоров Г.В., Егоров А.Г. Анализ закономерностей списания речных круизных судов и прогноз состава речного флота с определением наиболее востребованных типов судов для конверсии и модернизации // Морской Вестник. 2019. № 1 (69). C. 21-27.

10. Сайт компании «Thurgau Travel» [Электронный ресурс]. URL: https://www.thurgautravel.ch/ (дата обращения 28.10.2019).

11. Сайm «Водный транспорт» [Электронный ресурс]. URL: https://fleetphoto.ru/ (дата обращения 28.10.2019).

\section{REFERENCES}

1. Egorov G.V., Egorov A.G., Kalugin Ya.V. (2019). Prakticheskaya realizaciya konceptov sovremennykh kruiznykh sudov smeshannogo plavaniya [Practical realization of concepts of modern river-sea cruise ships]. Materialy X mezhdun. nauchnotekhn. konf. "Innovatsii $v$ sudostroenii $i$ okeanotekhnike» (Proceedings of X international Sc-Tech. conference "Innovations in shipbuilding and ocean technique»). Nikolayev, 106-109 [in Russian].

2. Egorov A.G. (2019). Principy proektirovaniya rechnykh kruiznykh sudov s ispolzovaniem sudov-donorov [Principles of design of river cruise ships with usage of ships-donors]. Morskoy Vestnik (Maritime Reporter), 3 (71), 9-15 [in Russian]. 
ВІСНИК

ОДЕСЬКОГО НАЦІОНАЛЬНОГО

МОРСЬКОГО УНІВЕРСИТЕТУ

№ 3 (60), 2019
HERALD

OF THE ODESSA NATIONAL

MARITIME UNIVERSITY

№ 3 (60), 2019

3. Egorov A.G. (2019). Analiz otechestvennogo opyta pereoborudovaniya kruiznykh passazhirskikh sudov [Analysis of native experience of modernization of cruise passenger ships]. Morskoy Vestnik (Maritime Reporter), 2 (70), 9-14 [in Russian].

4. Egorov A.G. (2018). Rechnye kruiznye passazhirskie suda: innovacionnye resheniya $i$ ikh primenimost pri konversii [River cruise passenger ships: innovative solutions and their applicability in conversion works]. Visnuk ONMU (Reporter of Odessa National Maritime University), 4 (57), 23-52 [in Russian].

5. «Vodohod» cruise company website. Retrieved from: https:// vodohod.com/cruises/life/health/ (access date 28.10.2019).

6. «Mosturflot» cruise company website. Retrieved from: https:// www.mosturflot.ru/post?id=29188 (access date 28.10.2019).

7. "Mosturflot» cruise company website. Retrieved from: https:// www.mosturflot.ru/post? id=29348 (access date 28.10.2019).

8. "Infoflot» cruise company website. Retrieved from: https:// www.infoflot.com/news/new7980/ (access date 28.10.2019).

9. Egorov G.V., Egorov A.G. (2019). Analiz zakonomernostej spisaniya rechnykh kruiznykh sudov $i$ prognoz sostava rechnogo flota s opredeleniem naibolee vostrebovannykh tipov sudov dlya konversii i modernizacii [Analysis of trends of decommissioning of river cruise vessels and prognosis of structure of river fleet with definition of most demanded types of vessels for conversion and modernization]. Morskoy Vestnik (Maritime Reporter), 1 (69), 21-27 [in Russian].

10. «Thurgau Travel» cruise company website. Retrieved from: https:// www.thurgautravel.ch/ (access date 28.10.2019).

11. "Fleet photo» company website. Retrieved from: https:// fleetphoto.ru/ (access date 28.10.2019).

Стаття надійшла до редакиії 27.11.2019 